\title{
Penerapan Metode Diskusi Kelompok untuk Meningkatkan Minat Belajar Siswa di MI Darul Ulum Genengan
}

\author{
Yuana Indah Sriati ${ }^{1}$, Ajeng Nurya Tri Ningsih ${ }^{2}$, Vegi Teria Sofiandira ${ }^{3}$, Adin \\ Fauzi $^{4}$
}

1,2,3,4Universitas Islam Balitar, Blitar, Indonesia

*Corresponding Author: yuanaindah196@gmail.com

\begin{abstract}
Info Artikel
Diterima : 01/10/2021

Direvisi: $15 / 10 / 2021$

Disetujui: $22 / 10 / 2021$

Abstract. Referring to the Instruction of the Minister of Home Affairs Number 38 of 2021 which explains, for regions that have entered levels 1 to 3 in the Covid-19 distribution map, they can open limited face-to-face learning. In response to this, many schools in Blitar Regency have implemented limited face-to-face learning, one of which is MI Darul Ulum Genengan. Besides, one of the problems that will likely occur when face-to-face learning is carried out is the lack of interest in learning when the lesson takes place. This is because students have been doing online learning at home for a long time, and when they have to return to school, there will certainly be many differences, such as the way the material is delivered and the material obtained. Therefore, the activities we carry out are aimed at helping students increase their interest in learning in class, by using the Group Discussion method. The results of this activity indicate that students are more motivated by conducting group discussions, they are more enthusiastic when studying or working with their friends, and students become more creative. It is hoped that later this activity can be followed up by teachers at MI Darul Ulum to increase interest in learning and can provide motivation during class learning.
\end{abstract}

Keywords: Interest in learning, motivation, discussion groups

\begin{abstract}
Abstrak. Mengacu pada Instruksi Menteri Dalam Negeri Nomor 38 Tahun 2021 yang menerangkan, bagi daerah yang sudah memasuki level 1 sampai 3 dalam peta persebaran covid-19 sudah bisa membuka PTM terbatas. Menanggapi hal tersebut maka sekolah-sekolah yang berada di Kabupaten Blitar banyak yang sudah memberlakukan PTM terbatas, salah satunya adalah MI Darul Ulum Genengan. Disamping itu semua, salah satu permasalahan yang nantinya akan mungkin terjadi saat pembelajaran tatap muka dilaksanakan adalah kurangnya minat belajar disaat pelajaran berlangsung. Hal ini dikarenakan siswa sudah lama melakukan pembelajaran secara online dirumah, dan saat mereka harus kembali ke sekolah pastinya akan ada banyak sekali perbedaan seperti cara penyampaian materi serta materi yang didapatkan. Oleh karena itu, kegiatan yang kami lakukan ini bertujuan untuk membantu siswa dalam meningkatkan minat belajar dikelas, dengan menggunakan metode Group Discussion/ Diskusi Kelompok. Hasil dari kegiatan ini menunjukkan bahwa siswa lebih termotivasi dengan dilakukannya kelompok diskusi, mereka lebih bersemangat saat belajar maupun mengerjakan bersama teman mereka selain itu siswa menjadi lebih kreatif. Sehingga diharapkan nantinya kegiatan ini bisa ditindak lanjuti oleh guru di MI Darul Ulum untuk meningkatkan minat belajar serta dapat memberikan motivasi selama belajar di kelas.
\end{abstract}

Kata Kunci: Minat belajar, motivasi, kelompok diskusi

How to Cite: How to Cite: Sriati, Y.I., Ningsih, A. N. T., Sofiandira, F.T., \& Fauzi, A. (2021). Penerapan Metode Diskusi Kelompok untuk Meningkatkan Minat Belajar Siswa di MI Darul Ulum Genengan. Prima Abdika: Jurnal Pengabdian Masyarakat, 1(4), 192-197. https://doi.org/10.37478/abdika.v1i4.1264 License.

\section{Pendahuluan}

Mengacu pada Instruksi Menteri Dalam Negeri Nomor 38 Tahun 2021 yang menerangkan, bagi daerah yang sudah memasuki level 1 sampai 3 dalam peta persebaran covid-19 sudah bisa membuka PTM terbatas. Pembelajaran tatap muka ini menerapkan system $50 \%$ kehadiran siswa dari seluruh siswa yang ada. Hal ini tentunya disambut baik oleh seluruh lapisan instansi pendidikan, pengajar, siswa serta orang tua siswa. Seperti halnya di MI Darul Ulum Genengan, yang juga sudah menerapkan PTM terbatas yang dimulai pada bulan September dengan tetap menerapkan protokol kesehatan yang ketat. 
Keputusan pemerintah untuk mendorong melakukan PTM terbatas inipun tentunya sudah melewati pemikiran yang panjang. Seperti yang telah disampaikan oleh Menteri Komunikasi dan Informatika Johnny G. Plate dalam keterangan tertulis PTM terbatas perlu dipercepat karena pelaksanaan Pembelajaran Jarak Jauh (PJJ) berkepanjangan dapat beresiko negative pada anak. Diantaranya adalah untuk menghindari ancaman putus sekolah, menghindari penurunan capaian belajar anak, serta untuk menghindari resiko psikososial/kondisi individu mencakup aspek psikis dan social pada anak selama PJJ (Putri, 2021).

Seperti yang telah diketahui bersama, bahwa Pembelajaran Jarak Jauh (PJJ) tidak selamanya membawa dampak yang baik bagi siswa. Banyak sekali kendala yang dialami selama melakukan PJJ diantaranya kurang memadainya fasilitas layanan internet setiap siswa, kurangnya pemahaman akan materi yang diberikan oleh guru, serta kurangnya minat serta motivasi selama belajar dirumah. Kerap kali siswa akan mengeluh jika mereka harus dituntut untuk mengerjakan tugas-tugas yang banyak. Dan juga atmosfer lingkungan belajar yang kurang nyaman juga mempengaruhi minat mereka dalam belajar dirumah. Sehingga saat diterapkannya kembali PTM terbatas, baik guru siswa maupun orangtua siswa akan sangat terbantu.

Dalam kegiatan pengabdian masyarakat ini, kami menerapkan metode Group Discussion/diskusi kelompok bagi siswa. Kegiatan ini bertujuan untuk membantu siswa dalam meningkatkan minat belajar dikelas. Dengan metode ini kami harapkan nantinya siswa akan lebih bersemangat dan lebih termotivasi selama mengikuti pembelajaran dikelas. Menurut Mc. Donald yang dikutip oleh Hamalik (2002) motivasi adalah suatu perubahan energi di dalam diri pribadi seseorang yang ditandai dengan timbulnya afektif, dan reaksi untuk mencapai suatu tujuan. Dengan adanya motivasi inilah yang diharapkan siswa akan dapat mengikuti pembelajaran dikelas dengan baik dan tanpa adanya paksaan. Sedangkan minat menurut Slameto dalam Nisa (2015) adalah suatu kecenderungan tetap untuk memperhatikan dan mengenang beberapa kegiatan. Lebih lanjut dijelaskan bahwa minat adalah suatu rasa suka dan ketertarikan pada suatu hal.

\section{Metode Pelaksanaan}

Kegiatan pengabdian masyarakat ini diselenggarakan di MI Darul Ulum Genengan, Kecamatan Doko Kabupaten Blitar. Kami memilih sekolah ini dikarenakan kurangnya inovasi serta terobosan baru dari guru-guru disekolah dalam melakukan kegiatan belajar mengajar. Yang mana hal ini menyebabkan siswa kurang memiliki semangat belajar serta mudah jenuh selama mengikuti pembelajaran dikelas. Penerapan metode Group Discussion ini diterapkan di kelas 3, dengan jumlah 12 siswa disetiap pertemuannya. Kegiatan ini dilaksanakan terhitung sejak tanggal 7 September sampai dengan 18 September 2021, dan dilaksanakan 4 hari dalam seminggu yaitu hari selasa, rabu, jumat, sabtu. 
Metode Group Discussionn atau diskusi kelompok ini kami pilih dengan tujuan untuk membantu siswa dalam meningkatkan minat belajar dikelas. Menurut Hariyanto (2010) kegiatan diskusi kelompok merupakan kegiatan yang dilakukan dengan melibatkan lebih dari satu individu yang dapat dijadikan sebagai alternative dalam membantu memecahkan persoalan. Pada pelaksanaanya, pertama adalah penjelasan materi sesuai dengan pelajaran pada hari itu. Setelah itu, barulah diberikan tugas untuk dikerjakan secara berdiskusi. Untuk setiap kelompoknya berisikan 3 sampai 4 siswa. Untuk hasil diskusi, nantinya akan di panggil secara acak perwakilan dari tiap kelompok. Karena pemilihan perwakilannya secara acak, maka tiap anggota kelompok harus mengerti dan paham tentang materi diskusi. Dan diakhir jam pelajaran, mereka harus membacakan hasil diskusi dengan bahasa mereka sendiri.

Untuk bisa menumbuhkan sikap kerjasama serta berpikir kreatif, maka pada pertemuan-pertemuan selanjutnya akan dibentuk kelompok diskusi dengan anggota yang berbeda. Metode diskusi kelompok ini memiliki beberapa manfaat, diantaranya adalah memberikan kesempatan kepada siswa untuk berpartisipasi secara langsung, meningkatkan berpikir kritis dan partisipasi, serta memberikan kesempatan kepada siswa untuk menguji, mengubah dan mengembangkan pandangan dalam kelompok (Juniati, 2017). Indikator keberhasilan dalam pelaksanaan metode ini adalah keaktifan siswa dalam melakukan diskusi kelompok, selain itu juga keberagaman hasil pemikiran yang disampaikan diakhir diskusi juga menjadi poin penting dalam keberhasilan metode ini.

\section{Hasil dan Pembahasan}

Menurut Moedjiono dalam Juniati (2017) metode diskusi merupakan materi dimana sejumlah orang membicarakan secara bersama-sama melalui tukar pendapat tentang suatu topic atau pokok bahasan masalah untuk memecahkan dan mencari jawaban dari suatu masalah berdasarkan semua fakta yang memungkinkan untuk itu. Pada tahap berdiskusi, pertama-tama siswa akan diberikan garis besar tentang materi yang dibahas. Selanjutnya siswa akan diminta untuk berdiskusi tentang hal-hal yang lebih terperinci lagi serta diminta untuk mencari contoh. Apabila salah satu dari anggota kelompok mengalami kesulitan untuk memahami materi tersebut, maka tugas dari anggota lain adalah untuk membantu menjelaskan dengan bahasa yang mereka mudah pahami. Apabila tetap mengalami kesulitan maka nantinya akan kami bantu. Setelah melakukan diskusi, selanjutnya adalah pembacaan hasil diskusi didepan kelas oleh perwakilan kelompok. Apabila nantinya ada pertanyaan seputar hasil diskusi tersebut, maka akan kami jelaskan secara lebih lanjut.

Dalam pelaksanaan metode ini, salah satu topic yang dibahas adalah wawancara. Sebelumnya sudah dijelaskan secara singkat apa itu definisi dari wawancara, unsur-unsur wawancara, serta hal hal yang dilakukan sebelum melakukan wawancara. Selanjutnya adalah membentuk kelompok untuk berdiskusi, satu kelompok terdiri dari 3 sampai 4 siswa. Gambar 1 adalah pembagian kelompok di kelas. 


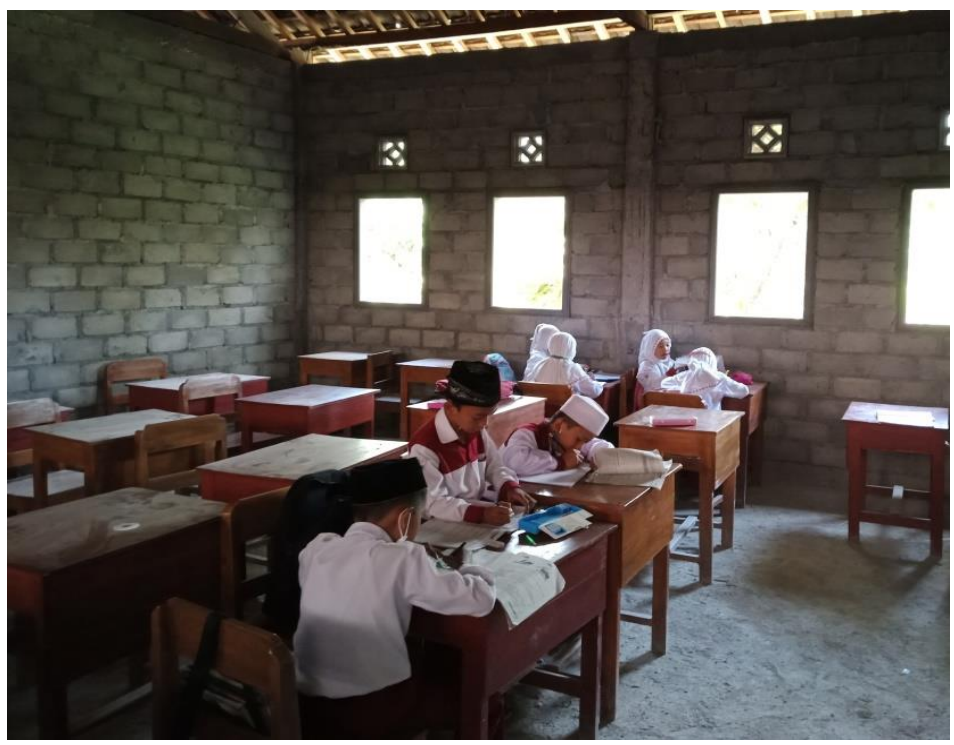

Gambar 1. Pembagian kelompok di kelas

Dalam diskusi kali ini siswa diminta untuk menganalisis teks wawancara yang sudah disiapkan. Siswa diminta untuk menentukan topik dari wawancara, siapakah yang berperan sebagai pewawancara dan narasumber, serta hasil yang didapat dari kegiatan wawancara tersebut. Gambar 2 adalah siswa yang sedang melakukan diskusi kelompok.

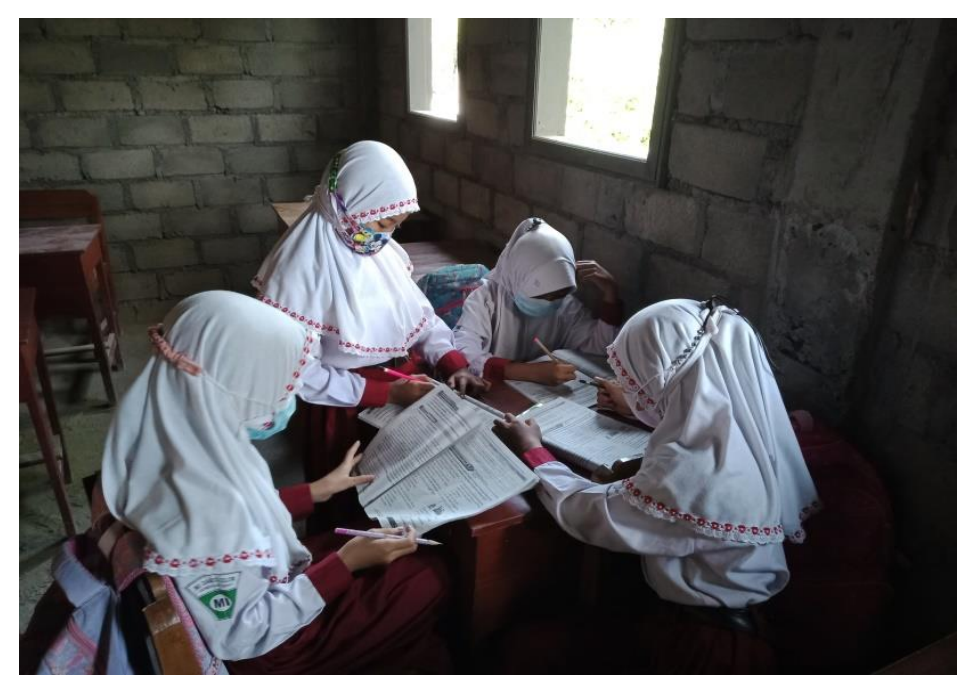

Gambar 2. Siswa melakukan diskusi kelompok

Setelah mereka berdiskusi tentang unsur-unsur dalam teks wawancara, tugas selanjutnya adalah membuat teks wawancara singkat dengan topik yang bebas. Dari sini kreatifitas mereka akan terlihat dari berbagai topik yang mereka tentukan. Setelah itu perwakilan dari masing masing kelompok diminta untuk mempraktekkan kegiatan wawancara didepan kelas. Gambar 3 adalah praktek wawancara didepan kelas. 


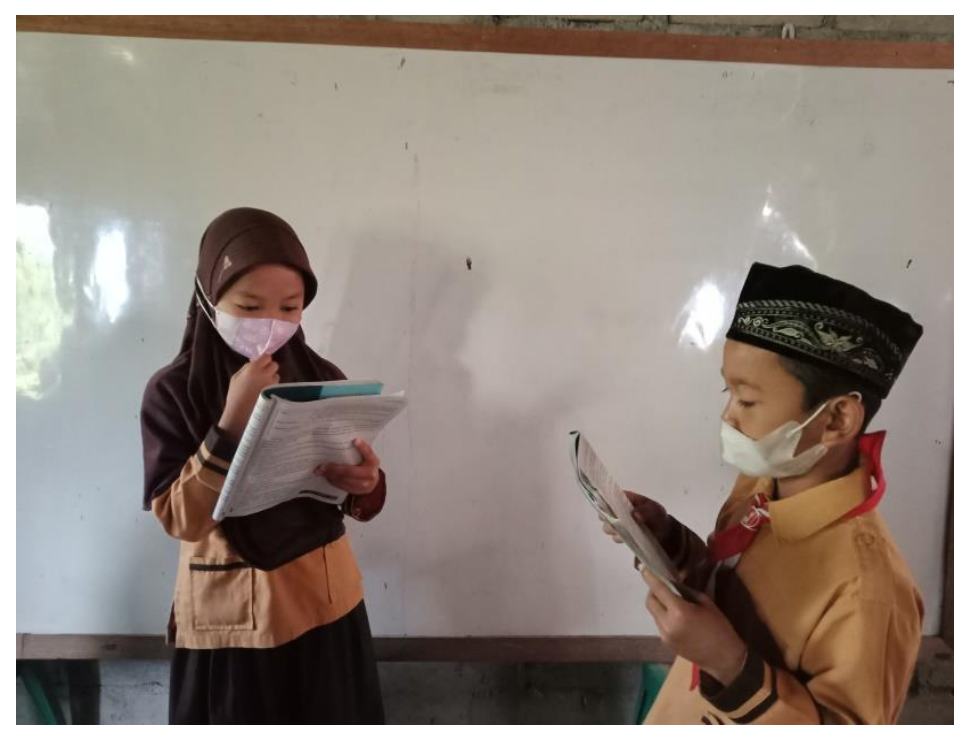

Gambar 3. Praktek melakukan wawancara

Dari hasil seluruh kegitan berdiskusi, nantinya diakhir pembelajaran akan ada kesimpulan akhir mengenai materi wawancara serta sesi tanya jawab bagi para siswa. Di sesi inilah peran pendamping belajar (guru) diperlukan, nantinya guru akan memberikan kesimpulan tentang materi wawancara yang telah mereka diskusikan sebelumnya. Dan juga guru akan meluruskan hasil diskusi mereka yang masih perlu dikoreksi. Menurut Setiawan (2011) dalam pelaksanaan diskusi guru berperan sebagai pemimpin diskusi, atau guru dapat mendelegasikan tugas sebagai pemimpin itu kepada siswa, walaupun demikian guru masih harus mengawasi pelaksanaan diskusi yang dipimpin oleh siswa.

Dari pelaksanaan metode Group Discussion/diskusi kelompok yang diterapkan di MI Darul Ulum Genengan, kami menyimpulkan bahwa kegiatan ini dapat dikatakan berhasil. Yang dibuktikan dengan keaktifan siswa selama mereka berdiskusi, dan juga menambah minat mereka dalam mempelajari materi yang didiskusikan. Jika sebelumnya mereka terlihat kurang percaya diri dalam menyampaikan pendapatnya di kelas, melalui kelompok diskusi ini mereka lebih leluasa dalam berpendapat. Hal ini dapat menumbuhkan motivasi belajar siswa di kelas. Meskipun dalam prosesnya, masih ada siswa yang masih malu-malu dalam menyuarakan pendapat mereka ataupun juga terlihat pasif. Tetapi jika dilihat secara keseluruhan, metode ini dapat dikatakan berhasil diterapkan.

\section{Simpulan dan Tindak Lanjut}

Kegiatan pembelajaran dengan menerapkan metode kelompok diskusi ini bertujuan untuk membantu siswa dalam meningkatkan minat belajar dikelas dan juga bertujuan untuk melatih siswa agar bekerja secara berkelompok. Dilihat dari hasil pelaksanaanya, metode ini mampu melatih siswa agar berani dalam menyuarakan pemikirannya serta dapat melatih untuk berpikir secara kreatif. Selama pelaksanaan diskusi, siswa mampu menjawab pertanyaan yang diberikan secara benar dan juga mampu 
menjelaskan kepada anggota kelompok yang masih belum mengerti tentang jawaban tersebut. Dalam tugas pembuatan teks wawancara pun, mereka dapat berdiskusi dengan baik mengenai pemilihan topic untuk wawancara serta pertanyaan-pertanyaan apa yang ingin diajukan. Sehingga kedepannya, penulis berharap agar para guru mampu menindak lanjuti penerapan metode kelompok diskusi ini. Karena dengan penerapan metode ini dapat melatih siswa dalam bekerja secara kelompok, serta melatih kepercayaan diri. Dan juga dalam pelaksanaanya, metode kelompok diskusi ini dapat diterapkan dalam setiap mata pelajaran yang ada. Guru dapat menyesuaikannya sesuai dengan target pembelajaran masing-masing.

\section{Daftar Pustaka}

Hamalik, O. (2002). Proses Belajar Mengajar. Jakarta: Bumi Aksara

Hariyanto, H. (2010). Pengertian Diskusi Kelompok. Diakses dari : http:/ / belajarpsikologi.com/pengertian-diskusi-kelompok

Instruksi Menteri Dalam Negeri Nomor 38 Tahun 2021. Diakses dari : http://kominfo.jatimprov.go.id

Juniati. (2017). Peningkatan Hasil Belajar Matematika Melalui Metode Drill dan Diskusi Kelompok pada Siswa Kekas VI SD. Scholaria: Jurnal Pendidikan dan Kebudayaan, Vol 7 (3), 283-291

Nisa, A. (2015). Pengaruh Perhatian Orang Tua dan Minat Belajar Siswa Terhadap Prestasi Belajar Ilmu Pengetahuan Sosial. Faktor Jurnal Ilmiah Kependidikan, Vol.II (1), 5. .

Putri, I. (2021,September 4). 3 Alasan Pemerintah Percepat Sekolah Tatap Muka Terbatas.
https://news.detik.com/berita

Setiawan, D. A. (2011). Metode Pembelajaran Diskusi, Simulasi dan Pemberian Tugas. Diakses dari : http://sdn2ketro.blogspot.co.id/2011/02/metode-pembelajaran-diskusisimulasi.html 